\title{
Self - Efficacy as Predictors of Academic Achievement of Secondary Schools Students in Obio Akpor Local Government Area of Rivers State. Nigeria.
}

\author{
Love Nwamadi (Ph.D) ${ }^{1 *}$, Rosemary Obiagaeri Ekechukwu. (Ph.D $)^{2}$ \\ ${ }^{1}$ Department of Educational Psychology, Guidance and Counselling Ignatius Ajuru University of Education \\ Rumuolumeni, Rivers State, Nigeria \\ ${ }^{2}$ Department of Educational Psychology, Guidance and Counselling Faculty of Education. University of Port \\ Harcourt. Nigeria
}

*Corresponding Author: Love Nwamadi, Department of Educational Psychology, Guidance and Counselling Ignatius Ajuru University of Education Rumuolumeni, Rivers State, Nigeria

\begin{abstract}
The study investigated self-efficacy as predictor of academic achievement among secondary school students of Obio/Akpor Local Government Area of Rivers State. The study adopted the correlational research design. Two research questions as well as two corresponding hypotheses guided the study. The population of the study will be made up of all 14,784 senior secondary school students (SSS 1, 2 and 3) in 16 public secondary schools in Obio/Akpor Local Government Area of Rivers State. A sample of 339 students comprising of 174 male and 164 female were drawn from the population using stratified purposive random sampling technique. Two instruments were used for data collection; Self-Efficacy Scale (SES) and Students' Academic Achievement Test (SAAT). The reliability of the instrument was established using Cronbach Alpha technique and the reliability coefficient obtained was 0.93 and 0.71 respectively. Simple linear regression associated with ANOVA was used to answer the research questions and test the hypotheses. The findings revealed that self-efficacy predicted academic achievement for both male and female students significantly. Based on the findings of the study, it was recommended among others that the self-efficacy of students should be improved by the subject teachers and parents in other for students to be confident in the ability to perform better.
\end{abstract}

Keywords: Self-efficacy and Academic Achievement

\section{INTRODUCTION}

Academic achievement of students especially at the secondary school level is not only a pointer to the effectiveness or otherwise of schools but a major determinant to the future of youths in particular and the nation in general. The medium through which the attainment of individuals and the nation's educational goals can be achieved is learning. Learning outcomes have become a phenomenon of interest to all and this account for the reason why scholars have been working hard to unravel factors that predict academic achievement (Aremu \& Sokan, 2002). Adeyemo (2001) opined that the major goal of the school is to work towards attainment of academic excellence by students. According to him, the school may have other peripheral objectives, but emphasis is always placed on the achievement of sound scholarship. The students' academic achievement plays an important role in producing the best quality graduates who will become great leaders that can produce the man power needed for the country's economic and social development (Ali, 2009). Halawah (2006) stated that academic achievement is accomplished by actual execution of class work in the school setting. It is typically assessed by using teachers' ratings, class tests and examinations organized by the academic institutions or by the educational boards. Academic achievement to Sunitha (2005) is the knowledge acquired and skills developed in school subjects, generally indicated by marks obtained in tests in annual examination.

Virtually everybody concerned with education places premium on academic achievement; excellent academic achievement of children is often the expectation of parents (Osiki, 2001). The declining quality of education in the country and the breeding of graduates with little technical know-how have resulted in serious setbacks to the industrial development of the nation. Studies have suggested that 
various variables are capable of predicting academic achievement of secondary school students. Such variables may be psychological (self-efficacy, locus of control, achievement motivation etc.) and social (gender and type of school etc). Investigation of these variables has produced several findings by researchers. For instance, self-efficacy according to Ormrod (2006) is the measure of one's competences to complete tasks and reach goals. It influences every aspect of human endeavours. It could be referred to as a person's belief in his or her ability to successfully accomplish a specific task. Wikipedia encyclopedia (2018) defines self-efficacy as the extent or strength of one's belief in one's own ability to persist and succeed with a task and that high and low self-efficacy determine whether or not a person will choose to take a challenging task or write it off as being impossible.

Bandura as cited in Onukwufor (2012) described self-efficacy as an optimistic belief in one's own competence and effectiveness, and meeting and maintaining high performance standards. This is applicable to students in their academic achievement as the ability and the will power to conquer inability to excel is based on their self-efficacy power especially in subjects like English studies and mathematics as core subjects in Nigeria schools. Self-efficacy can be categorized as high or low. Low self-efficacy in students destroys their motivation, lower their aspiration, interfere with their cognitive abilities and adversely affect their physical health. For Synder and Lopez (2007), self-efficacy as what individuals believe they can accomplish using their skills under certain circumstances. They further explained that the fundamental principles behind self-efficacy is that individuals are more likely to employ themselves in activities in which they have high self-efficacy and less likely to engage in those they do not. Ofole and Okopi (2012) opined that students with low self-efficacy are academically at risk whereas a student with high self-efficacy braces up and meets the academic rigour and excels better in school, because he or she perceives himself or herself as being capable of doing well in school. Conversely, a learner noted for having low academic self-efficacy inhibits good academic achievement because of the tendency to see himself or herself as being unable to cope with the academic challenge. Koura and Al-Hebaishi (2014) stressed that high or low self-efficacy is all about thoughts that the students hold about themselves which affect their academic achievement directly or otherwise. These thoughtful feelings either aid or hinder their academic progress. Studies by Adeyemo, (2007) and Akomolafe (2010) reported that self-efficacy significantly predicts academic achievement among secondary school students. Klassen, Krawchuk, Rajani (2008) also found out that self-efficacy is a strong predictor of academic achievement among secondary school students. However, some studies have been reported contrary findings. For instance, Loo and Choy (2013) found out that self-efficacy had very little positive effect on students' academic achievement.

\section{Statement of the Problem}

Students need to be confident of themselves as that could lead them to face academic challenges in school. Low self-efficacy could be another reason for failure, hopelessness and failed dreams in the careers of students. Not being able to accomplish their aspirations and goals could lead students' to behavioural problems. Students poor academic achievement has resulted in low and negative remarks about the educational standard in Nigeria when compared to other nations. It has made job recruitment processes difficult as there fewer persons with the required pass grade to fill in vacant positions in most organizations. Poor academic achievement has also led to negative labeling of students by their peers and even family members, thus causing some students to becoming school drop-out. Therefore, it is important that this study examines self-efficacy as predictor of academic achievement among secondary school students in Obio/Akpor Local Government Area of Rivers State, Nigeria.

\subsection{Aim and Objectives of the Study}

The study examined self-efficacy as predictor of academic achievement among secondary school students in Obio/Akpor Local Government Area of Rivers State, Nigeria. Specifically, the study sought to;

1. Find out the extent to which self-efficacy predicts academic achievement among secondary school students.

2. Determine the extent to which self-efficacy predicts academic achievement of male secondary school students in Obio/Akpor Local Government Area of Rivers State.

3. Ascertain the extent to which self-efficacy predicts academic achievement of female secondary school students in Obio/Akpor Local Government Area of Rivers State 
Self - Efficacy as Predictors of Academic Achievement of Secondary Schools Students in Obio Akpor Local Government Area of Rivers State. Nigeria.

\subsection{Research Questions}

The following research questions guided the study;

1. To what extent does self-efficacy predict academic achievement of secondary school students in Obio/Akpor Local Government Area of Rivers State?

2. To what extent does self-efficacy predict academic achievement of male secondary school students in Obio/Akpor Local Government Area of Rivers State?

3. To what extent does self-efficacy predict academic achievement of female secondary school students in Obio/Akpor Local Government Area of Rivers State?

\subsection{Hypotheses}

The following hypotheses which were tested at 0.05 level of significance guided the study;

1 Self-efficacy does not significantly predict the academic achievement of secondary school students in Obio/Akpor Local Government Area of Rivers State

2 Self-efficacy does not significantly predict the academic achievement of male secondary school students in Obio/Akpor Local Government Area of Rivers State

3 Self-efficacy does not significantly predict the academic achievement of female secondary school students in Obio/Akpor Local Government Area of Rivers State

\section{Methodology}

The study adopted the correlational design. The population of the study will be made up of all 14,784 senior secondary school students (SSS 1, 2 and 3) in 16 public secondary schools in Obio/Akpor Local Government Area of Rivers State. A sample of 339 students comprising of 174 male and 164 female were drawn from the population using stratified purposive random sampling technique. Two instruments were used for data collection; Self-Efficacy Scale (SES) and Students' Academic Achievement Test (SAAT). The reliability of the instrument was established using Cronbach Alpha technique and the reliability coefficient obtained was 0.93 and 0.71 respectively. Simple linear regression associated with ANOVA was used to answer the research questions and test the hypotheses.

\subsection{Data Analysis}

Simple regression associated with ANOVA was used to answer and test the hypotheses.

Research Question One: To what extent does self-efficacy predict academic achievement of secondary school students in Obio/Akpor Local Government Area of Rivers State?

Hypothesis One: Self-efficacy does not significantly predict the academic achievement of secondary school students in Obio/Akpor Local Government Area of Rivers State

Table1. Simple regression for the prediction of the relative contribution of self-efficacy on students' academic achievement

\begin{tabular}{|l|l|l|l|l|l|l|l|}
\hline & Model & $\mathbf{r}$ & $\mathbf{r}^{\mathbf{2}}$ & $\mathbf{a d j r}^{\mathbf{2}}$ & $\mathbf{d f}$ & $\mathbf{F}$ & sig \\
\hline \multirow{2}{*}{1} & Regression & 172 & 0.030 & 0.027 & 1 & 10292 & 0.001 \\
\cline { 2 - 8 } & Residual & & & & 337 & & \\
\hline
\end{tabular}

Table 1 shows that self-efficacy had an r-value of 172 was obtained with a corresponding r-square value of 0.030 and an adjusted r-square value of 0.027 which implies that self-efficacy predicted about $2.7 \%$ of the academic achievement of secondary school students in Obio/Akpor Local Government Area of Rivers State. Furthermore, the testing of the hypothesis using ANOVA associated with simple regression revealed that an F-value of 10.292 was obtained with an associated p-value of 0.001 , which was lesser than 0.05 the chosen alpha level. The result therefore shows that self-efficacy significantly predicts academic achievement of secondary school students in Obio/Akpor Local Government Area of Rivers State.

Research Question Two: To what extent does self-efficacy predict academic achievement of male secondary school students in Obio/Akpor Local Government Area of Rivers State?

Hypotheses Two: Self-efficacy does not significantly predict the academic achievement of male secondary school students in Obio/Akpor Local Government Area of Rivers State 
Self - Efficacy as Predictors of Academic Achievement of Secondary Schools Students in Obio Akpor Local Government Area of Rivers State. Nigeria.

Table2. Simple regression analysis on the extent self-efficacy predicts male secondary school students' academic achievement

\begin{tabular}{|l|l|l|l|l|l|l|l|}
\hline & Model & $\mathbf{r}$ & $\mathbf{r}^{\mathbf{2}}$ & $\mathbf{a d j r}^{\mathbf{2}}$ & $\mathbf{d f}$ & $\mathbf{F}$ & sig \\
\hline \multirow{2}{*}{1} & Regression & 0.196 & 0.038 & 0.033 & 1 & 6.839 & 0.010 \\
\cline { 2 - 8 } & Residual & & & & 172 & & \\
\hline
\end{tabular}

The data analysis on table 2 shows that an R-value of 0.196 was gotten with a corresponding R-square value of 0.038 and an adjusted $\mathrm{R}$-value of 0.033 which indicate that self-efficacy predicted about $3.3 \%$ of the male secondary school student's academic achievement in Obio/Akpor Local Government Area of Rivers State. Moreover, the testing of the hypothesis using ANOVA associated with simple regression revealed that an F-value of 6.839 was obtained at 1 and 172 degrees of freedom with an associated p-value of 0.010 , which was less than the 0.05 chosen alpha level. The results thus imply that self-efficacy significantly predicts male secondary school student's academic achievement in Obio/Akpor Local Government Area of Rivers State.

Research Question Three: To what extent does self-efficacy predict academic achievement of female secondary school students in Obio/Akpor Local Government Area of Rivers State?

Hypothesis Three: Self-efficacy does not significantly predict the academic achievement of female secondary school students in Obio/Akpor Local Government Area of Rivers State

Table3. Simple regression analysis on the extent self-efficacy predicts female secondary school students' academic achievement

\begin{tabular}{|l|l|l|l|l|l|l|l|}
\hline & Model & $\mathbf{r}$ & $\mathbf{r}^{2}$ & $\mathbf{a d j r}^{2}$ & $\mathbf{d f}$ & F & sig \\
\hline \multirow{2}{*}{1} & Regression & 0.165 & 0.027 & 0.021 & 1 & 4.567 & 0.034 \\
\cline { 2 - 8 } & Residual & & & & 163 & & \\
\hline
\end{tabular}

a. Dependent variable: SAAT

b. Predictor Constant self-efficacy

From the data analysis in table 3 , it can be seen that an R-value of 0.165 was obtained with a corresponding R-square value of 0.027 and an adjusted R-value of 0.021 which implies that selfefficacy predicted about $2.1 \%$ of female secondary school students' academic achievement in Obio/Akpor Local Government Area of Rivers State. However, the testing of the hypothesis using ANOVA associated with simple regression revealed that an F-value of 4.567 was obtained at 1 and 163 degrees of freedom with an associated p-value of 0.034 , which was lesser than 0.05 of the chosen alpha level. Therefore, the result shows that self-efficacy significantly predict female secondary school students' academic achievement in Obio/Akpor Local Government Area of Rivers State.

\section{SUMMARY OF THE FINDINGS}

The results obtained after data analysis are summarized below;

1. Self-efficacy significantly predicts academic achievement of secondary school students in Obio/Akpor Local Government Area of Rivers State.

2. The findings also showed that self-efficacy significantly predicted academic achievement of both male and female secondary school students in Obio/Akpor Local Government Area of Rivers State.

\subsection{Discussion of the Findings}

The finding of the study revealed that self-efficacy significantly predicts academic achievement of secondary school students in Obio/Akpor Local Government Area of Rivers State. The null hypothesis of no significant prediction of self-efficacy on secondary school students academic achievement was rejected, hence it was concluded that self-efficacy significantly predicts academic achievement of secondary school students in Obio/Akpor Local Government Area of Rivers State. The finding of the present study is in agreement with earlier studies by Abd-Elmotab and Saha (2013) who found out that academic self-efficacy has a positive relationship with academic achievement of secondary school students. Bartmote-Aufflick (2018) found out that developing a positive selfefficacy improve the academic performance of students and promote choices in which learners feel more competent. Ofole and Okopi (2012) also found out that students with low self-efficacy are 
academically at risk whereas a student with high self-efficacy braces up and meets the academic rigour and excels better in school, because he or she perceives himself or herself as being capable of doing well in school.

The result also revealed that self-efficacy significantly predicted academic achievement of both male and female secondary school students in Obio/Akpor Local Government Area of Rivers State. The findings of the present study is in agreement with that of Ekeh and oladayo (2015) who found out high level of self-efficacy significantly predicted of both male and female students academic achievement. Klassen, Krawchuk, Rajani (2008) also found out that self-efficacy is a strong predictor of academic achievement among male and female secondary school students.

\section{CONCLUSiON}

Virtually everybody concerned with education places premium expectations on the academic achievement of students. Students' poor academic achievement has resulted in low and negative remarks about the educational standard in Nigeria when compared to other nations. It has made job recruitment processes difficult as there fewer persons with the required pass grades to fill in vacant positions in most organizations. Poor academic achievement has also led to negative labeling of students by their peers and even family members, thus causing some students to becoming school drop-out. Therefore, this study examined self-efficacy as predictor of academic achievement of secondary school students in Obio/Akpor Local Government Area of River State, and has shown that self-efficacy significantly predicts academic achievement of both male and female secondary school students in Obio/Akpor Local Government Area of River State.

\section{RECOMMENDATIONS}

1. Self-efficacy of students should be improved by the school subject teachers and parents in other for students to be confident in the ability to perform better.

2. School counsellors should counsel students on ways to improve their self-efficacious ability to achieve their academic goals.

3. Teachers should apply reinforcement techniques in encouraging students who they noticed are not doing well in their academics.

\section{REFERENCES}

[1] Abd-Elimotaleb, M. \& Saha, S. K. (2013). The role of academic self-efficacy as a mediator variable between perceived academic climate and academic performance. Journal of Education and Learning, vol. 2, No, 2,

[2] Adeoye, H., \& Emeka, E. A., (2012). Emotional intelligence and self-efficacy as determinants of academic achievement in English Language among students in Oyo State, senior secon-dary schools. http/www.proquest.com/

[3] Adeyemo, D.A. (2007). Moderating influence of emotional intelligence on the link between academic selfefficacy and achievement ofuniversity students. Psychology Developing Societies, 1 9(2), 199-213.

[4] Akomolafe, M.J. (2010). Measured influence of self-efficacy and gender on secondary school students' academic performance in OndoState, Nigeria. Educational Thought, 7(1), 1-13.

[5] Aremu, O. A., \& Sokan, B. O. (2003). A multi-causal evaluation of academic performance of Nigerian learners: Issues and implications for national development. Department of Guidance and Counselling, University of Ibadan, Ibadan.

[6] Bartimote-Aufflick, K., Bridgmen, A., Walker, R., Sharma, M., \& Smith, L. (2016). The study, evaluation and improvement of University student self-efficacy studies in higher education. 1918-1942

[7] Ekeh, P. U., \& Oladayo, O. T. (2015). Optimism and self-efficacy as predictors of academic achievement among special needs learners. International Journal of Academic Research and Reflections, 3, 7.

[8] Klassen, R. M., Krawchuk, L. L., \& Rajani, S. (2008). Academic procrastination of undergraduates: low self-efficacy to self-regulate as determinants of career maturity among Nigerian adolescents.

[9] Koura, A., \& Al-Hebaishi, A. 2014.The relationship between multipleintelligences, self- efficacy and academic achievement of Saudi Arabia giftedand regular intermediate students. Saudi Arab Educational Research Journal International 3(1), 12-18

[10] Loo, C. W., \& Choy, J. L. F. (2013). Sources of self-efficacy influencing academic performance of engineering students. American Journal of Educational Research, 1(3), 86-92 
Self - Efficacy as Predictors of Academic Achievement of Secondary Schools Students in Obio Akpor Local Government Area of Rivers State. Nigeria.

[11] Ofole, N. M., \& Okopi, F. (2012). Therapeutic effect of Rational Emotive therapy on self-efficacy in improving academic achievement. Psychology, 92, 544-555.

[12] Ormrod, J. E. (2006). Educational psychology: Developing learners (5th ed.). Upper Saddle River, N.J.: Pearson/Merrill Prentice Hall.

Citation: Love Nwamadi (Ph.D), Rosemary Obiagaeri Ekechukwu. (Ph.D ). "Self - Efficacy as Predictors of Academic Achievement of Secondary Schools Students in Obio Akpor Local Government Area of Rivers State. Nigeria." International Journal of Humanities Social Sciences and Education (IJHSSE), vol 7, no. 11, 2020, pp. 21-26. doi: https://doi.org/10.20431/2349-0381.0711004.

Copyright: () 2020 Authors. This is an open-access article distributed under the terms of the Creative Commons Attribution License, which permits unrestricted use, distribution, and reproduction in any medium, provided the original author and source are credited. 